\title{
A Systematic Review and Meta-analysis of Therapeutic options against SARS-CoV-2
}

Viveksandeep Thoguluva Chandrasekar ${ }^{1}$, Bhanuprasad Venkatesalu ${ }^{2}$, Harsh K. Patel ${ }^{3}$, Marco

Spadaccini $^{4}$, Jacob Manteuffel ${ }^{2}$ and Mayur Ramesh ${ }^{2}$

\section{Author affiliations:}

${ }^{1}$ University of Kansas Medical Center, Kansas City, Kansas, United States

${ }^{2}$ Henry Ford hospital, Detroit, Michigan, United States.

${ }^{3}$ Ochsner Clinic Foundation, New Orleans, Louisiana, United States

${ }^{4}$ Humanitas University and Research Hospital, Rozzano, Milan, Italy

\section{Corresponding author:}

Viveksandeep Thoguluva Chandrasekar

University of Kansas Medical Center

Kansas City, Kansas 66160

United States

Ph. Number: 516-590-9978

Email id: viveksandeepvs@gmail.com

Fax: 913-588-3877

Running title: Meta-analysis of treatment options for SARS-CoV-2

Keywords: SARS-CoV-2, COVID-19, meta-analysis, hydroxychloroquine, HCQ 


\section{Article summary line:}

The use of hydroxychloroquine was associated with increased mortality and adverse event rates in Severe acute respiratory syndrome-related coronavirus-2 infection and other therapeutic interventions did not show any difference in outcomes

\section{Abbreviations}

SARS-CoV-2 - Severe Acute Respiratory Syndrome related Coronavirus-2

HCQ - Hydroxychloroquine

COVID-19 - Coronavirus disease 2019

PRISMA - Preferred Reporting Items for Systematic Reviews and Meta-Analyses

RCT - Randomized Controlled Trials

NNT - Number needed to treat

$\mathrm{NNH}$ - Number needed to harm

IQR - Interquartile range

CI - Confidence interval

OR - Odds ratio

$\mathrm{NIH}$ - National Institute of Health

FDA - Food and Drug Administration

WHO - World Health Organization

Author approval: All authors have seen and approved the submission of this manuscript

Competing interests: None

Declarations: None

Funding: None 
medRxiv preprint doi: https://doi.org/10.1101/2020.05.20.20108365; this version posted May 23, 2020. The copyright holder for this preprint (which was not certified by peer review) is the author/funder, who has granted medRxiv a license to display the preprint in perpetuity.

All rights reserved. No reuse allowed without permission.

\begin{abstract}
:
Importance

Treatment options for Severe acute respiratory syndrome-related coronavirus-2 (SARS-CoV-2) are limited with no clarity on the efficacy and safety profiles.
\end{abstract}

\title{
Objective
}

To assess if the effect estimate of any intervention improves the outcomes and safety profile.

\section{Data sources}

PubMed, Embase, Cochrane Central were searched from December 1, 2019 to May 11, 2020.

\section{Study selection}

Any prospective/retrospective clinical study on SARS-CoV-2 patients $\geq 18$ years of age with report on therapeutic interventions.

\section{Data synthesis and extraction}

Data was screened and extracted by two independent investigators.

\section{Main outcomes and measures}

The primary outcome was all-cause in-hospital mortality. The secondary outcomes were rates of mechanical ventilation, viral clearance, adverse events, discharge, progression to severe disease, median time for clinical recovery and anti-viral clearance. Pooled rates and odds ratios $(\mathrm{OR})$ were calculated.

\section{Results}

A total of 29 studies with 5207 participants were included in the analysis. The pooled all-cause in-hospital mortality rate was $12.8 \%$ (95\%CI: 8.1\%-17.4\%) in intervention arm. There was no significant difference in mortality between both arms overall (OR: 1.36, 95\% CI: 0.97-1.89). The mortality was significantly higher in the Hydroxychloroquine (HCQ) group compared to control: (1.86, 95\% CI: $1.38-2.50)$. The need for mechanical ventilation in patients with mild-moderate disease was $13.5 \%$ vs $9.8 \%$ in intervention and control groups, with no significant difference (OR: 1.58, 95\% CI: $0.60-4.15$ ). The median duration for viral clearance in the intervention arm was 6.1 (IQR: 4.3 - 8.8) days and control arm was 9 (IQR: 4.5 -14) days, with no significant difference between the groups $(\mathrm{p}=0.37)$. There was no significant difference between pooled adverse event rates in intervention and control groups: $34 \%$ vs $29.5 \%$ (OR: 1.44, 95\% CI: $0.70-2.94)$, respectively. However, incidence of adverse events was significantly higher in HCQ sub-group (OR: 3.88, 95\% CI: $1.60-9.45, \mathrm{I}^{2}=0 \%$ ). There was no significant difference in other secondary outcomes. 
medRxiv preprint doi: https://doi.org/10.1101/2020.05.20.20108365; this version posted May 23, 2020. The copyright holder for this preprint (which was not certified by peer review) is the author/funder, who has granted medRxiv a license to display the preprint in perpetuity.

All rights reserved. No reuse allowed without permission.

\section{Conclusion and relevance}

The use of hydroxychloroquine was associated with increased mortality and adverse event rates. No other therapeutic intervention including Lopinavir/Ritonavir, Remdesivir or Tocilizumab seem to alter the natural course of the disease. There is a further need for well-designed randomized clinical trials.

\section{Introduction}

Severe acute respiratory syndrome-related coronavirus-2(SARS-CoV-2) is the $7^{\text {th }}$ virus of the coronavirus family known to infect humans(1). By March, the World health Organization had declared SARS-CoV-2 as a pandemic, the third pandemic in the $21^{\text {st }}$ century after the SARS outbreak in 2003 and H1N1 influenza in 2009. SARS-CoV-2 tends to cause a plethora of symptoms with fever, cough, myalgia, fatigue, loss of taste, appetite and diarrhea to name a few. It is also known to affect multiple organ systems leading to acute respiratory distress syndrome, encephalitis, myocarditis, hepatitis, acute kidney injury and hypercoagulable state leading to stroke and pulmonary embolism. The COVID-19 disease caused by SARS-CoV-2 can be classified as mild, moderate, severe and critical disease based on clinical, imaging and laboratory parameters(2).The natural history of the disease is such that most patients typically have mild disease with spontaneous resolution of symptoms by 10-14 days needing symptomatic management and home self-quarantine. Elderly population, as well as patients with medical comorbidities are at higher risk of developing moderate to severe disease(3). As per the Chinese Center for Disease Control and Prevention data in a cohort of 72,314 patients, clinical deterioration tends to typically occur in the second week of onset of symptoms with need for hospitalization and close monitoring in $14 \%$ of patients and around $5 \%$ of patients require invasive ventilation (4). Several therapeutic interventions like Hydroxychloroquine (HCQ), Chloroquine, Remdesivir, Corticosteroids, Tocilizumab and convalescent plasma therapy have been attempted, but currently there is no known intervention that has reduced mortality in 
medRxiv preprint doi: https://doi.org/10.1101/2020.05.20.20108365; this version posted May 23, 2020. The copyright holder for this preprint (which was not certified by peer review) is the author/funder, who has granted medRxiv a license to display the preprint in perpetuity.

All rights reserved. No reuse allowed without permission.

COVID-19 patients. These questions bring into focus the need of a comprehensive systematic review of the published literature to collate the available evidence. The aim of this systematic review and meta-analysis is to assess if any intervention provides mortality benefit, other clinically relevant outcomes and also ascertain the safety profile.

\section{Methods:}

This systematic review was performed as per the Preferred Reporting Items for Systematic Reviews and Meta-Analyses (PRISMA) recommendations(5). The protocol is provided as Appendix 1. Institutional review board approval was not required for this study since no patient identifiers were disclosed.

\section{Data sources}

A systematic electronic search was performed in PubMed/MEDLINE, Embase, Cochrane Central, Google Scholar, MedRxiv databases to identify published and pre-published studies reporting outcomes related to interventions for SARS-CoV-2 infection, from December 1, 2019 to May 11, 2020. The Medical Subject Heading/ Entree terms is provided in Appendix 2. An independent review of the abstracts and full paper articles was done (VT and BV). The duplicates were removed and the titles of articles were evaluated. The full-length papers of the shortlisted articles were assessed for the eligibility criteria. The articles that fulfilled the inclusion criteria were shortlisted for final systematic review. The included study references were cross-searched for additional studies. The articles were reviewed independently by two authors (VT and BV) and any disagreement was resolved by consensus with a third author (MR). Reasons for excluding studies were documented. 
medRxiv preprint doi: https://doi.org/10.1101/2020.05.20.20108365; this version posted May 23, 2020. The copyright holder for this preprint (which was not certified by peer review) is the author/funder, who has granted medRxiv a license to display the preprint in perpetuity.

\section{Eligibility criteria}

The inclusion criteria were as follows: 1) Studies reporting outcomes for treatment in SARSCoV-2 infection 2) All studies including randomized controlled trials (RCTs), prospective, retrospective and case series 3) Full length studies 4) Patients more than 18 years of age. Exclusion criteria were: 1) Pre-clinical studies, epidemiological and descriptive studies without intervention for SARS-CoV-2 patients 2) Abstracts.

\section{Data extraction and quality assessment:}

The data was extracted by two authors independently into pre-defined forms. The following data was extracted from the studies: first author, mean age, study design, number of patients, gender, rates of: mortality, clinical improvement, mechanical ventilation, progression to severe disease, viral clearance, discharge and adverse events. Data for both intervention and control arms (for available studies) were extracted separately. Quality assessment was performed only for RCTs as most of the other studies were retrospective in nature with short hospital courses for duration of treatment. Cochrane risk bias tool was used for study quality assessment forRCTs(6).

\section{Definitions and Outcomes:}

The definitions of outcomes that were assessed is provided as Appendix 3. The intervention arm consisted of patients receiving the drug or the therapeutic intervention while the control arm patients received standard of care treatment for SARS-CoV-2 without a specific intervention. The primary outcomes were the all-cause mortality in the intervention arm and in comparison, 
medRxiv preprint doi: https://doi.org/10.1101/2020.05.20.20108365; this version posted May 23, 2020. The copyright holder for this preprint (which was not certified by peer review) is the author/funder, who has granted medRxiv a license to display the preprint in perpetuity.

All rights reserved. No reuse allowed without permission.

with control arm. The secondary outcomes were rates of clinical recovery, need for mechanical ventilation, viral clearance, radiological improvement, discharge and adverse events in intervention arm and comparison with control arm. Median duration for viral clearance and clinical recovery were also calculated from available studies. Number needed to treat (NNT) and number needed to harm $(\mathrm{NNH})$ were defined as the number of patients who needed to be treated to provide benefit or harm in at least 1 patient, comparing intervention and control arms for respective outcomes.

\section{Statistical analysis}

Percentages for categorical variables and median with interquartile range (IQR) for continuous variables were presented. Differences in medians were calculated using the Mann-WhitneyWilcoxon test. Proportions with pooled rates with $95 \%$ confidence intervals (CI) were calculated for individual arms. Odds ratios (OR) comparing with control arm was reported with 95\% CI and p-value <0.05 was considered statistically significant. Random effects model described by DerSimonian and Laird were used for analysis. Corresponding forest plots were constructed for both primary and secondary outcomes. NNT and NNH were calculated using the inverse of the differences in benefit or harm between the intervention and control arms for the respective outcomes. Study heterogeneity was assessed using Inconsistency index ( $\mathrm{I}^{2}$-statistic) with low, moderate, substantial and considerable heterogeneity indicated by $\mathrm{I}^{2}$-value of $0-30 \%, 31 \%-60 \%$, $61 \%-75 \%$ and $76 \%-100 \%$, respectively. All analyses were performed using statistical softwares Open Meta analyst (CEBM, Brown University, Rhode Island, USA) and Review Manager Version 5.3 (The Nordic Cochrane Center, Copenhagen, Denmark). Sub-group analyses were 
medRxiv preprint doi: https://doi.org/10.1101/2020.05.20.20108365; this version posted May 23, 2020. The copyright holder for this preprint (which was not certified by peer review) is the author/funder, who has granted medRxiv a license to display the preprint in perpetuity.

All rights reserved. No reuse allowed without permission.

performed for the following, when data was available and also to address heterogeneity in primary outcome if present: 1) Intervention specific, 2) Disease severity specific, 3) RCTs only.

\section{Results:}

\section{Study search and study characteristics}

The literature search resulted in 3664 articles, of which 65 articles underwent full review and 29 were included in the final analysis (Figure 1)(3, 7-34). Among included studies, 19 were performed in China, 4 in France, 4 in USA, 1 in Brazil and 1 in South Korea. Eight studies were RCTs, 4 were prospective studies and the remaining 17 were retrospective studies. Fifteen studies were published and the remaining were pre-published. Seventeen studies had a drug or intervention being tested with a control group for comparison. For intervention, 12 studies used HCQ based treatment (2 studies had azithromycin along with HCQ in same arm, 3 had azithromycin in separate arm and 1 study was comparison of HCQ with Lopinavir/ Ritonavir), 5 studies used antiviral agents (2 studies with Lopinavir/ Ritonavir, 1 with Baloxavir/ Marboxil and Favipravir and 2 with Remdesivir), 2 were Tocilizumab based single arm studies, 5 used corticosteroids (3 with control arm) and 5 studies were single-arm plasma therapy based. There were 3,624 patients in the intervention arm (mean age: $55.9 \pm 8.4$ years, $62 \%$ males) and 1,583 patients (mean age: $52.5 \pm 8.5$ years, $60.7 \%$ males) in the control arm. The median duration of follow-up was 14 days (IQR: 9 - 24.5) and the range was 6-32 days across all studies. The demographics and study characteristics have been provided in Table $\mathbf{1 .}$

\section{Risk of bias assessment}

Eight RCTs were part of this meta-analysis. Of these 3 were at low risk of bias and 5 were at high risk. Risk of bias summary has been provided in Appendix 4. 
medRxiv preprint doi: https://doi.org/10.1101/2020.05.20.20108365; this version posted May 23, 2020. The copyright holder for this preprint (which was not certified by peer review) is the author/funder, who has granted medRxiv a license to display the preprint in perpetuity.

\section{Primary outcome: All-cause mortality}

Twenty-four studies provided data on mortality in the intervention arm and the pooled all-cause in-hospital mortality rate was $12.8 \%$ (95\%CI: $8.1 \%-17.4 \%$ ) for a median follow up duration of 14 (IQR: 10-18.5) days (Table 2). Comparing the mortality between the intervention arm and control arms, 10 studies $(\mathrm{n}=3894)$ provided the data, with a pooled rate of $17.1 \%(95 \% \mathrm{CI}$ : 9.1\%-27.4\%) in the intervention arm and $14.8 \%$ (95\% CI: 9.4\% - 20.1\%) in the control arm, with no significant difference between the two groups (OR: $1.36,95 \%$ CI: $0.97-1.89, \mathrm{I}^{2}=46 \%, \mathrm{p}=$ 0.07) (Figure 2A). The NNH was calculated to be 43 . When analysis was restricted to only 4 HCQ based studies $(n=3152)$, the mortality was significantly higher in the HCQ group (OR: 1.86, 95\% CI: $\left.1.38-2.50, \mathrm{I}^{2}=29 \%, \mathrm{p}<0.001\right)(\mathrm{NNH}-13)$.(Figure $\left.2 \mathbf{B}\right)$ A further sub-group analysis for only 2 studies $(n=212)$ which used only HCQ for treatment without any other confounders like azithromycin and the mortality was still significantly higher in the HCQ group (OR: 2.17, 95\% CI: 1.26-3.72, $\left.\mathrm{I}^{2}=43 \%\right)(\mathrm{NNH}-9)$. Comparing intervention and control arms, sub-group analysis performed for antiviral studies only $(n=550)(\mathrm{OR}-0.83,95 \%$ CI: $0.49-$ 1.38), steroid based studies $(\mathrm{n}=192)(\mathrm{OR}: 0.96,95 \%$ CI: $0.40-2.31)$, moderate to severe disease patients $(\mathrm{n}=2184)(\mathrm{OR}: 1.09,95 \%$ CI: $0.56-1.57)$, severe disease patients $(\mathrm{n}=627)$ (OR: 0.87, 95\% CI: 0.58-1.31) (Appendix figure 1) and RCTs only $(\mathrm{n}=550)(\mathrm{OR}: 0.83$, 95\%CI: 0.49 - 1.38) (Appendix figure 2), did not show a statistically significant difference between the two groups (Appendix table 1).

\section{Secondary outcomes:}

\section{Rate of mechanical ventilation:}


medRxiv preprint doi: https://doi.org/10.1101/2020.05.20.20108365; this version posted May 23, 2020. The copyright holder for this preprint (which was not certified by peer review) is the author/funder, who has granted medRxiv a license to display the preprint in perpetuity.

All rights reserved. No reuse allowed without permission.

Nine studies $(\mathrm{n}=1456)$ reported need for mechanical ventilation in patients in the intervention arm, with a pooled intubation rate of $18.6 \%$ (95\% CI: $10.9 \%-26.3 \%)$ (Table 2). Comparing the 7 studies $(n=2317)$ which also provided information on control population, the pooled rates in the intervention and control arms were $13.5 \%$ vs $9.8 \%$, respectively with no significant difference between the two groups (OR: $1.58,95 \%$ CI: $\left.0.60-4.15, \mathrm{I}^{2}=85 \%\right)(\mathrm{NNT}-27)$

(Figure 3A). There was no significant difference in the outcome when analysis was restricted to HCQ and anti-viral based studies.

\section{Viral clearance:}

Fifteen studies reported data on either the proportion of patients with antiviral clearance at the end of the study or the median duration for antiviral clearance. The pooled proportion of patients with antiviral clearance in the intervention arm $(n=393)$ was $80 \%(95 \%$ CI: $70.7 \%-89.4 \%)$. Comparing the 6 studies $(n=461)$ reporting data on antiviral clearance in intervention and control groups, the pooled rates were $74.9 \%$ vs $66.8 \%$, respectively with no significant difference between the two groups (OR: $1.86,95 \%$ CI: $\left.0.76-4.54, \mathrm{I}^{2}=58 \%\right)(\mathrm{NNT}-10)$ (Appendix figure 3). When the analysis was restricted to HCQ based and anti-viral based studies, there was still no significant difference between the two groups. The median duration for antiviral clearance in the intervention arm $(n=308)$ was $6.1($ IQR: $4.3-8.8)$ days and in the control arm $(\mathrm{n}=170)$ was 9 (IQR: $4.5-14)$ days, with no significant difference between the two groups $(\mathrm{p}=0.37)$

\section{Clinical recovery:}

Fourteen studies reported data on either the proportion of patients who had clinical recovery or median time to clinical recovery. The pooled rate of proportion of patients with clinical recovery 
medRxiv preprint doi: https://doi.org/10.1101/2020.05.20.20108365; this version posted May 23, 2020. The copyright holder for this preprint (which was not certified by peer review) is the author/funder, who has granted medRxiv a license to display the preprint in perpetuity.

All rights reserved. No reuse allowed without permission.

in the intervention arm $(\mathrm{n}=558)$ was $79.7 \%$ (95\% CI: 78.9\% - 88.4\%). Comparing the 4 studies reporting data in intervention and control arms, the pooled rates were $64.1 \%$ and $52.8 \%$ (NNT 9), respectively with no significant difference between the two groups (OR: $1.41,95 \%$ CI: 0.99 $2.02, \mathrm{I}^{2}=0 \%$ ) (Figure 3B). Decrease in oxygen requirements in both groups was reported in 2 studies $(n=375)$, with no significant difference between both the groups (OR: $1.05,95 \%$ CI: $\left.0.65-1.71, \mathrm{I}^{2}=3 \%\right)$.

The median time to clinical recovery was 14 (IQR: $8.2-19)$ days in the intervention group $(\mathrm{n}=$ $451)$ and 16 (IQR: $14.3-22)$ days in the control group $(\mathrm{n}=263)$, with no significant difference between the two groups $(\mathrm{p}=0.25)$

\section{Progression to severe disease:}

Nine studies reported data on worsening of clinical status in the hospital in mild-moderate severity patients, with a pooled rate of $11.6 \%$ (95\% CI: $5.4 \%-17.8 \%)$ in the intervention arm (n = 387) over a median duration of 13 (IQR: 9.5 - 19.5) days. Comparing the pooled rates in five studies reporting the outcome in both groups $(\mathrm{n}=386)$, the pooled rates were $13.4 \%$ and $12.8 \%$ in the intervention and control groups, respectively with no significant difference between the two groups (OR: 1.19, 95\% CI: $\left.0.67-2.13, \mathrm{I}^{2}=0 \%\right)$. Sub-group analysis restricted to HCQ based and antiviral studies also did not reveal any significant difference.

\section{Adverse events:}

Sixteen studies $(n=791)$ reported the rate of adverse events in the intervention group with a pooled adverse event rate of $23.3 \%(95 \%$ CI: $12.1 \%-34.5 \%)$. Six studies $(n=754)$ compared intervention and control groups with pooled adverse event rates of $34 \%$ and $29.5 \%$ respectively, with no significant difference between the two groups (OR: 1.44, 95\% CI: $0.70-2.94)$ (NNT - 
medRxiv preprint doi: https://doi.org/10.1101/2020.05.20.20108365; this version posted May 23, 2020. The copyright holder for this preprint (which was not certified by peer review) is the author/funder, who has granted medRxiv a license to display the preprint in perpetuity.

All rights reserved. No reuse allowed without permission.

22) (Figure 4A). On sub-group analysis, the incidence of adverse events was significantly higher in the HCQ group (OR: 3.88, 95\% CI: $1.60-9.45, \mathrm{I}^{2}=0 \%$ ) (Figure 4B) with a NNH of 7, but there was no significant difference for studies with antiviral agents.

There was also no significant difference between both the groups in radiological improvement and discharge rates. The individual pooled rates and ORs are provided in Table 2. Sub-group analysis for only RCTs for available outcomes are provided in Appendix table 2.

\section{Discussion:}

In this systematic review and meta-analysis of 5207 patients from 29 studies, pooled outcome for any therapeutic intervention including HCQ, Remdesivir, Lopinavir/Ritonavir, Steroids, Tocilizumab, Convalescent plasma therapy did not show a survival benefit compared to control arms. HCQ use was associated with significantly increased all-cause inpatient mortality and adverse event rates. There were no significant benefits with any therapeutic intervention in changing the natural history of SARS-CoV-2 infection assessed in terms of rate of mechanical ventilation, viral clearance, time to discharge, time to clinical recovery and radiological improvement.

HCQ increases the endosomal $\mathrm{pH}$ and prevents fusion of the host membrane with SARS-CoV-2 thereby interfering with the viral replication cycle. Several pre-clinical studies showed invitro activity against SARS-CoV-2 leading to clinical use of HCQ in COVID-19 disease(35, 36). An initial case series of 26 patients from France comparing HCQ and control groups suggested that HCQ leads to rapid anti-viral clearance in $70 \%$ of patients compared to $12.5 \%$ in controls. This study was fraught with methodological inconsistencies like enrollment of asymptomatic individuals, omission of 6 patients from analysis (HCQ patients of whom one died and 3 were 
medRxiv preprint doi: https://doi.org/10.1101/2020.05.20.20108365; this version posted May 23, 2020. The copyright holder for this preprint (which was not certified by peer review) is the author/funder, who has granted medRxiv a license to display the preprint in perpetuity.

All rights reserved. No reuse allowed without permission.

transferred to ICU)(9). In a randomized study of 62 patients from China, patients treated with HCQ showed radiological improvement in resolution of lung lesions as well as reduction in clinical progression of disease. The commonality of the initial studies on HCQ were relatively small sample size, inappropriate control groups, lack of clarity in defining the study outcomes(14). Two larger prospective RCTs from France and Brazil show that HCQ/chloroquine use is associated with increased incidence of cardiac events with no survival benefit $(12,16)$. In view of conflicting data outcomes, the National Institute of Health (NIH), USA recommends that there is insufficient clinical data to recommend either for or against using chloroquine or hydroxychloroquine for the treatment of COVID-19(37).Despite these issues ,HCQ is currently one of the most commonly used medications in various parts of the world. Our analysis shows that HCQ based regimens had increased rate of mortality (NNH - 13) and adverse events (NNH - 7) compared to control patients. We hope our meta-analysis adds more evidence to dampen its use in view of lack of benefit and increased side effects.

Remdesivir was originally designed for use against Ebola. Remdesivir was studied in severe COVID-19 in China showed that the drug did not show any benefit in terms of time to recovery as well as 28 day mortality outcome, though the study was terminated prematurely in view of difficulty in patient accrual(22).ACTT NIH study showed that Remdesivir accelerated the time to recovery to 11 days compared to 15 days in the placebo arm with no mortality benefit. This prompted an emergency Food and Drug Ddministration (FDA) authorization for use in COVID19 patients. There are calls for Remdesivir to be taken as the standard of care control in future clinical studies. There have been questions raised about the NIH study due to limitations such as change in the primary endpoint of study after initiation of the trial, lack of mortality benefit; study in moderate disease patients who tend to recover spontaneously by the end of second 
medRxiv preprint doi: https://doi.org/10.1101/2020.05.20.20108365; this version posted May 23, 2020. The copyright holder for this preprint (which was not certified by peer review) is the author/funder, who has granted medRxiv a license to display the preprint in perpetuity.

All rights reserved. No reuse allowed without permission.

week(38).There are ethical concerns among the scientific community that drugs without proven mortality benefit or reduction in the need for ventilatory support may be promoted in view of aggressive pharmaceutical lobbying. The current pandemic rings echo bells of the $2009 \mathrm{H} 1 \mathrm{~N} 1$ pandemic and the desperate stockpiling of oseltamivir, whose proclaimed efficacy was claimed to be a byproduct of concealed information and aggressive lobbying by pharmaceutical companies(39) The published or preprint data for other drugs like Favipravir, Baloxavir/ Marboxil, corticosteroids, convalescent plasma is currently insufficient to make any specific recommendation and our meta-analysis also suggests the same.

Our meta-analysis shows that none of the so far studied interventions have a tangible benefit to change the course of disease outcomes with the current published evidence. The clinical studies that compare various interventions like the World health organization (WHO) sponsored solidarity trial that compares Remdesivir, chloroquine or hydroxychloroquine, lopinavir plus ritonavir, and interferon-beta with control arm and has all-cause mortality as the primary outcome is the need of the hour and the results are eagerly awaited(40).

The strengths of our study are as follows: We included 29 studies with more than 5200 patients in our analysis with various interventions. Our review is extensive, by including the available interventions and providing clinically relevant outcomes in comparison with controls. Several sub-group analyses were also performed based on study interventions and design. Heterogeneity in most of our outcomes was mild to moderate but we performed sub-group analysis in RCTs to further reduce the heterogeneity.

\section{Limitations}

Our study has several limitations. The study design, patient population and the outcomes assessed were variable in different studies. Even though the intervention arms were clearly 
medRxiv preprint doi: https://doi.org/10.1101/2020.05.20.20108365; this version posted May 23, 2020. The copyright holder for this preprint (which was not certified by peer review) is the author/funder, who has granted medRxiv a license to display the preprint in perpetuity.

All rights reserved. No reuse allowed without permission.

defined in most studies, some of the patients in those arms also received other medications and outcomes for such patients could not be excluded separately, which could have confounded the results. Different levels of disease severity of patients on study entry could lead to heterogeneity in outcomes but we tried to address it by performing sub-group analyses based on disease severity for outcomes when possible. Duration of follow-up was variable across studies and entire patient data at the end of study may not have been represented which is a limitation of the published literature. Adverse events reported include medication related adverse events and also symptoms in both groups, which could be related to SARS-CoV-2, but this was unanimously reported across all studies. The dose of medications, especially HCQ, was variable in studies and dose based analysis could not be performed. Data from pre-published studies were also included in our analysis but we had included them to provide a more comprehensive overview to prevent misinterpretation of results to the best of our capabilities. The results of our study should hence be interpreted with caution keeping these limitations in mind.

\section{Conclusions}

In this meta-analysis, there was no overall mortality or clinical benefit for most therapeutic interventions but the use of HCQ was associated with increased mortality rates and increased risk of adverse events in SARS-CoV-2 patients. None of the other therapeutic interventions like Lopinavir/Ritonavir, Remdesivir, Tocilizumab seemed to alter the natural clinical course of the disease based on the available literature. There is a need for well-designed randomized clinical trials to further investigate the efficacy and safety of various therapeutic interventions.

\section{Acknowledgements: None}

\section{Disclaimer: None}


medRxiv preprint doi: https://doi.org/10.1101/2020.05.20.20108365; this version posted May 23, 2020. The copyright holder for this preprint (which was not certified by peer review) is the author/funder, who has granted medRxiv a license to display the preprint in perpetuity.

All rights reserved. No reuse allowed without permission.

\section{Author bio:}

Dr. Thoguluva Chandrasekar is currently a Gastroenterology fellow at the University of Kansas

Medical Center. His research interest is in the field of Gastroenterology, primarily on Barrett's

esophagus and colorectal cancer. He will be specializing in Advanced Endoscopy training soon.

Given the global pandemic due to SARS-CoV-2 infection, his interest has also been to

investigate the GI manifestations in SARS-COV-2 infection and effect of various therapeutic

interventions in SARS-CoV-2.

\section{References}

1. The species Severe acute respiratory syndrome-related coronavirus: classifying 2019-nCoV and naming it SARS-CoV-2. Nature microbiology. 2020 Apr;5(4):536-44.

2. Gandhi RT, Lynch JB, Del Rio C. Mild or Moderate Covid-19. The New England journal of medicine. 2020 Apr 24.

3. Guan W-j, Ni Z-y, Hu Y, Liang W-h, Ou C-q, He J-x, et al. Clinical Characteristics of Coronavirus Disease 2019 in China. 2020;382(18):1708-20.

4. Wu Z, McGoogan JM. Characteristics of and Important Lessons From the Coronavirus Disease 2019 (COVID-19) Outbreak in China: Summary of a Report of 72]314 Cases From the Chinese Center for Disease Control and Prevention. Jama. 2020 Feb 24.

5. Moher D, Liberati A, Tetzlaff J, Altman DG. Preferred reporting items for systematic reviews and meta-analyses: the PRISMA statement. 2009;339:b2535.

6. Higgins JPT, Altman DG, Gøtzsche PC, Jüni P, Moher D, Oxman AD, et al. The Cochrane Collaboration's tool for assessing risk of bias in randomised trials. 2011;343:d5928.

7. Tang W, Cao Z, Han M, Wang Z, Chen J, Sun W, et al. Hydroxychloroquine in patients mainly with mild to moderate COVID-19: an open-label, randomized, controlled trial. 2020:2020.04.10.20060558.

8. Gautret P, Lagier JC, Parola P, Hoang VT, Meddeb L, Sevestre J, et al. Clinical and microbiological effect of a combination of hydroxychloroquine and azithromycin in 80 COVID-19 patients with at least a six-day follow up: A pilot observational study. Travel medicine and infectious disease. $2020 \mathrm{Mar}$ Apr;34:101663.

9. Gautret P, Lagier JC, Parola P, Hoang VT, Meddeb L, Mailhe M, et al. Hydroxychloroquine and azithromycin as a treatment of COVID-19: results of an open-label non-randomized clinical trial. International journal of antimicrobial agents. 2020 Mar 20:105949.

10. Geleris J, Sun Y, Platt J, Zucker J, Baldwin M, Hripcsak G, et al. Observational Study of Hydroxychloroquine in Hospitalized Patients with Covid-19. The New England journal of medicine. 2020 May 7. 
medRxiv preprint doi: https://doi.org/10.1101/2020.05.20.20108365; this version posted May 23 , 2020. The copyright holder for this preprint (which was not certified by peer review) is the author/funder, who has granted medRxiv a license to display the preprint in perpetuity.

All rights reserved. No reuse allowed without permission.

11. Mahevas M, Tran V-T, Roumier M, Chabrol A, Paule R, Guillaud C, et al. No evidence of clinical efficacy of hydroxychloroquine in patients hospitalized for COVID-19 infection with oxygen requirement: results of a study using routinely collected data to emulate a target trial. 2020:2020.04.10.20060699.

12. Molina JM, Delaugerre C, Le Goff J, Mela-Lima B, Ponscarme D, Goldwirt L, et al. No evidence of rapid antiviral clearance or clinical benefit with the combination of hydroxychloroquine and azithromycin in patients with severe COVID-19 infection. Medecine et maladies infectieuses. 2020 Mar 30.

13. Magagnoli J, Narendran S, Pereira F, Cummings T, Hardin JW, Sutton SS, et al. Outcomes of hydroxychloroquine usage in United States veterans hospitalized with Covid-19. 2020:2020.04.16.20065920.

14. Chen Z, Hu J, Zhang Z, Jiang S, Han S, Yan D, et al. Efficacy of hydroxychloroquine in patients with COVID-19: results of a randomized clinical trial. 2020:2020.03.22.20040758.

15. CHEN Jun LD, LIU Li, LIU Ping, XU Qingnian, XIA Lu, LING Yun, et al. A pilot study of hydroxychloroquine in treatment of patients with moderate COVID-19. 2020;49(2):215-9.

16. Borba MGS, Val FFA, Sampaio VS, Alexandre MAA, Melo GC, Brito M, et al. Effect of High vs Low Doses of Chloroquine Diphosphate as Adjunctive Therapy for Patients Hospitalized With Severe Acute Respiratory Syndrome Coronavirus 2 (SARS-CoV-2) Infection: A Randomized Clinical Trial. JAMA network open. 2020 Apr 24;3(4):e208857.

17. Bin Zhang, Shuyi Liu, Tan Tan, Wenhui Huang, Yuhao Dong, Luyan Chen, et al. Treatment With Convalescent Plasma for Critically III Patients With SARS Q1 -CoV-2 Infection. Chest. 2020.

18. Wu C, Chen X, Cai Y, Xia Ja, Zhou X, Xu S, et al. Risk Factors Associated With Acute Respiratory Distress Syndrome and Death in Patients With Coronavirus Disease 2019 Pneumonia in Wuhan, China. JAMA Internal Medicine. 2020.

19. Wang $Y$, Jiang W, He Q, Wang C, Wang B, Zhou P, et al. Early, low-dose and short-term application of corticosteroid treatment in patients with severe COVID-19 pneumonia: single-center experience from Wuhan, China. 2020:2020.03.06.20032342.

20. Xu X, Han M, Li T, Sun W, Wang D, Fu B, et al. Effective treatment of severe COVID-19 patients with tocilizumab. Proceedings of the National Academy of Sciences of the United States of America. 2020 Apr 29.

21. Luo P, Liu Y, Qiu L, Liu X, Liu D, Li J. Tocilizumab treatment in COVID-19: A single center experience.n/a(n/a).

22. Wang Y, Zhang D, Du G, Du R, Zhao J, Jin Y, et al. Remdesivir in adults with severe COVID-19: a randomised, double-blind, placebo-controlled, multicentre trial. Lancet (London, England). 2020. 23. Grein J, Ohmagari N, Shin D, Diaz G, Asperges E, Castagna A, et al. Compassionate Use of Remdesivir for Patients with Severe Covid-19. The New England journal of medicine. 2020 Apr 10.

24. Ye M, Fu D, Ren Y, Wang F, Wang D, Zhang F, et al. Treatment with convalescent plasma for COVID-19 patients in Wuhan, China.n/a(n/a).

25. Lu X, Chen T, Wang Y, Wang J, Zhang B, Li Y, et al. Adjuvant corticosteroid therapy for critically ill patients with COVID-19. 2020:2020.04.07.20056390.

26. Cao B, Wang Y, Wen D, Liu W, Wang J, Fan G, et al. A Trial of Lopinavir-Ritonavir in Adults Hospitalized with Severe Covid-19. 2020;382(19):1787-99.

27. Li Y, Xie Z, Lin W, Cai W, Wen C, Guan Y, et al. An exploratory randomized controlled study on the efficacy and safety of lopinavir/ritonavir or arbidol treating adult patients hospitalized with mild/moderate COVID-19 (ELACOI). 2020:2020.03.19.20038984.

28. Lou Y, Liu L, Qiu Y. Clinical Outcomes and Plasma Concentrations of Baloxavir Marboxil and Favipiravir in COVID-19 Patients: an Exploratory Randomized, Controlled Trial.

2020:2020.04.29.20085761. 
medRxiv preprint doi: https://doi.org/10.1101/2020.05.20.20108365; this version posted May 23, 2020. The copyright holder for this preprint (which was not certified by peer review) is the author/funder, who has granted medRxiv a license to display the preprint in perpetuity.

All rights reserved. No reuse allowed without permission.

29. Fang X, Mei Q, Yang T, Li L, Wang Y, Tong F, et al. Low-dose corticosteroid therapy does not delay viral clearance in patients with COVID-19. The Journal of infection. 2020 Apr 11.

30. Duan K, Liu B, Li C, Zhang H, Yu T, Qu J, et al. The feasibility of convalescent plasma therapy in severe COVID-19 patients: a pilot study. 2020:2020.03.16.20036145.

31. Shen C, Wang Z, Zhao F, Yang Y, Li J, Yuan J, et al. Treatment of 5 Critically III Patients With COVID-19 With Convalescent Plasma. Jama. 2020 Mar 27.

32. Huang M, Tang T, Pang P, Li M, Ma R, Lu J, et al. Treating COVID-19 with Chloroquine. Journal of Molecular Cell Biology. 2020.

33. Ahn JY, Sohn Y, Lee SH, Cho Y, Hyun JH, Baek YJ, et al. Use of Convalescent Plasma Therapy in Two COVID-19 Patients with Acute Respiratory Distress Syndrome in Korea. Journal of Korean medical science. 2020 Apr 13;35(14):e149.

34. Rosenberg ES, Dufort EM, Udo T, Wilberschied LA, Kumar J, Tesoriero J, et al. Association of Treatment With Hydroxychloroquine or Azithromycin With In-Hospital Mortality in Patients With COVID19 in New York State. Jama. 2020.

35. Vincent MJ, Bergeron E, Benjannet S, Erickson BR, Rollin PE, Ksiazek TG, et al. Chloroquine is a potent inhibitor of SARS coronavirus infection and spread. Virology journal. 2005 Aug 22;2:69.

36. Liu J, Cao R, Xu M, Wang X, Zhang H, Hu H, et al. Hydroxychloroquine, a less toxic derivative of chloroquine, is effective in inhibiting SARS-CoV-2 infection in vitro. Cell discovery. 2020;6:16.

37. COVID-19 Treatment Guidelines Panel Coronavirus Disease 2019 (COVID-19) Treatment Guidelines National Institutes of Health Available at https://wwwcovid19treatmentguidelinesnihgov/ Accessed 05/14/2020.

38. NIH clinical trial shows Remdesivir accelerates recovery from advanced COVID-19. https://wwwnihgov/news-events/news-releases/nih-clinical-trial-shows-remdesivir-acceleratesrecovery-advanced-covid-19. 2020.

39. Belluz J. Tug of war for antiviral drugs data. 2014;348:g2227.

40. https://doi.org/10.1186/ISRCTN83971151 I. Public health emergency SOLIDARITY trial of treatments for COVID-19 infection in hospitalized patients. 2020.

Table 1. Study design, demographics, intervention arms and outcomes 
medRxiv preprint doi: https://doi.org/10.1101/2020.05.20.20108365; this version posted May 23, 2020. The copyright holder for this preprint (which was not certified by peer review) is the author/funder, who has granted medRxiv a license to display the preprint in perpetuity. All rights reserved. No reuse allowed without permission.

\begin{tabular}{|c|c|c|c|c|c|c|c|c|c|c|c|c|c|c|}
\hline \multirow[t]{2}{*}{ Study } & \multirow[t]{2}{*}{$\begin{array}{c}\text { Countr } \\
y\end{array}$} & \multirow[t]{2}{*}{ Design } & \multirow{2}{*}{$\begin{array}{c}\mathrm{Ar} \\
\mathrm{m} \\
\mathbf{s}\end{array}$} & \multirow[t]{2}{*}{ Groups } & \multicolumn{3}{|c|}{$\begin{array}{l}\text { Number of } \\
\text { of Patients }\end{array}$} & \multicolumn{3}{|c|}{ Mean Age } & \multicolumn{3}{|c|}{ Males } & \multirow[t]{2}{*}{ Primary Outcome } \\
\hline & & & & & $\begin{array}{l}I \\
1\end{array}$ & 12 & C & 11 & 12 & $\mathbf{C}$ & I1 & 12 & C & \\
\hline $\begin{array}{l}\text { Chen Z } \\
\text { et al }^{13} \\
\end{array}$ & China & RCT & 2 & $\begin{array}{l}\text { HCQ vs } \\
\text { Control }\end{array}$ & $\begin{array}{l}3 \\
1 \\
\end{array}$ & & 31 & $\begin{array}{l}44 \\
.1 \\
\end{array}$ & & $\begin{array}{r}45 \\
.2 \\
\end{array}$ & 14 & & 15 & Clinical recovery \\
\hline $\begin{array}{l}\text { Chen J } \\
\text { et al }^{14}\end{array}$ & China & RCT & 2 & $\begin{array}{l}\text { HCQ vs } \\
\text { Control }\end{array}$ & $\begin{array}{l}1 \\
5\end{array}$ & & 15 & $\begin{array}{l}50 \\
.5\end{array}$ & & $\begin{array}{r}46 \\
.7\end{array}$ & 9 & & 12 & Viral clearance \\
\hline $\begin{array}{l}\begin{array}{c}\text { Borba et } \\
\text { al1 } 1^{5}\end{array}\end{array}$ & Brazil & RCT & 2 & $\begin{array}{c}\text { HCQ low } \\
\text { dose vs High } \\
\text { Dose }\end{array}$ & $\begin{array}{l}4 \\
1\end{array}$ & 40 & & $\begin{array}{l}54 \\
.7\end{array}$ & $\begin{array}{l}47 \\
.4\end{array}$ & & 10 & 10 & & Adverse events \\
\hline $\begin{array}{l}\text { Magagn } \\
\text { oli et } \\
\mathrm{al}^{12}\end{array}$ & USA & $\begin{array}{l}\text { Retrosp } \\
\text { ective }\end{array}$ & 3 & $\begin{array}{c}\text { HCQ vs } \\
\text { HCQ+AZ vs } \\
\text { Control }\end{array}$ & $\begin{array}{l}9 \\
7\end{array}$ & $\begin{array}{c}11 \\
3\end{array}$ & $\begin{array}{c}15 \\
8\end{array}$ & 70 & 68 & 69 & 97 & $\begin{array}{c}11 \\
3\end{array}$ & $\begin{array}{c}15 \\
8\end{array}$ & Mortality, Intubation \\
\hline $\begin{array}{l}\text { Molina J } \\
\text { et al }^{11}\end{array}$ & France & $\begin{array}{l}\text { Case } \\
\text { Series }\end{array}$ & 1 & $\begin{array}{l}\text { HCQ high } \\
\text { dose }+A Z\end{array}$ & $\begin{array}{l}1 \\
1 \\
\end{array}$ & & & & & & 7 & & & Viral clearance \\
\hline $\begin{array}{l}\text { Maheva } \\
\mathrm{s} \text { et al }{ }^{10}\end{array}$ & France & $\begin{array}{c}\text { Retrosp } \\
\text { ective }\end{array}$ & 2 & $\begin{array}{l}\text { HCQ vs } \\
\text { Control }\end{array}$ & $\begin{array}{l}8 \\
4\end{array}$ & & 97 & 59 & & 62 & 65 & & 63 & ICU, Mortality \\
\hline $\begin{array}{l}\text { Gautret } \\
\text { et al }\end{array}$ & France & $\begin{array}{l}\text { Prospe } \\
\text { ctive }\end{array}$ & 3 & $\begin{array}{c}\text { HCQ vs } \\
\text { HCQ+AZ vs } \\
\text { Control }\end{array}$ & $\begin{array}{l}1 \\
4\end{array}$ & 6 & 16 & $\begin{array}{l}51 \\
.2\end{array}$ & & $\begin{array}{l}37 \\
.3\end{array}$ & 9 & & 6 & Viral clearance \\
\hline $\begin{array}{l}\text { Gautret } \\
P \text { et al }{ }^{7}\end{array}$ & France & $\begin{array}{l}\text { Prospe } \\
\text { ctive }\end{array}$ & 1 & $\mathrm{HCQ}+\mathrm{AZ}$ & $\begin{array}{l}8 \\
0\end{array}$ & & & $\begin{array}{l}52 \\
.5\end{array}$ & & & 43 & & & $\begin{array}{l}\text { Clinical recovery, } \\
\text { Viral clearance, } \\
\text { Length of stay }\end{array}$ \\
\hline $\begin{array}{c}\text { Tang et } \\
\mathrm{al}^{6}\end{array}$ & China & $\begin{array}{l}\text { Open } \\
\text { label }\end{array}$ & 2 & $\begin{array}{l}\mathrm{HCQ} \text { vs } \\
\text { Control }\end{array}$ & $\begin{array}{l}7 \\
5 \\
\end{array}$ & & 75 & 48 & & $\begin{array}{c}46 \\
.1 \\
\end{array}$ & 42 & & 40 & Viral clearance \\
\hline $\begin{array}{l}\text { Huang } \\
\text { et }\left.^{3}\right|^{32}\end{array}$ & China & RCT & 2 & HCQ vs L/R & $\begin{array}{l}1 \\
0\end{array}$ & 12 & & $\begin{array}{l}41 \\
.5\end{array}$ & 53 & & 7 & 6 & & $\begin{array}{c}\text { Viral clearance, } \\
\text { imaging recover, } \\
\text { LOS }\end{array}$ \\
\hline $\begin{array}{l}\text { Geleris } \\
\text { et } \mathrm{al}^{9}\end{array}$ & USA & $\begin{array}{l}\text { Retrosp } \\
\text { ective }\end{array}$ & 2 & $\begin{array}{l}\text { HCQ vs } \\
\text { Control }\end{array}$ & $\begin{array}{l}8 \\
1 \\
1\end{array}$ & & $\begin{array}{c}56 \\
5\end{array}$ & & & & $\begin{array}{c}47 \\
4\end{array}$ & & $\begin{array}{c}30 \\
7\end{array}$ & Intubation, death \\
\hline $\begin{array}{l}\text { Rosenb } \\
\text { erg et } \\
\text { al(34) }\end{array}$ & USA & $\begin{array}{l}\text { Retrosp } \\
\text { ective }\end{array}$ & 4 & $\begin{array}{c}\mathrm{HCQ}+\mathrm{AZ} \\
\text { vs HCQ vs } \\
\mathrm{AZ} \text { vs control }\end{array}$ & $\begin{array}{l}7 \\
3 \\
5\end{array}$ & $\begin{array}{c}27 \\
1\end{array}$ & $\begin{array}{c}22 \\
1\end{array}$ & $\begin{array}{l}61 \\
.4\end{array}$ & $\begin{array}{l}65 \\
.5\end{array}$ & 64 & $\begin{array}{c}45 \\
6\end{array}$ & $\begin{array}{c}15 \\
8\end{array}$ & $\begin{array}{c}11 \\
0\end{array}$ & $\begin{array}{l}\text { All-cause mortality, } \\
\text { Cardiac arrest and } \\
\text { ECG abnormalities }\end{array}$ \\
\hline $\begin{array}{c}\text { Cao et } \\
\mathrm{al}^{25}\end{array}$ & China & RCT & 2 & $\begin{array}{l}\text { L/R vs } \\
\text { Control }\end{array}$ & $\begin{array}{l}9 \\
9 \\
\end{array}$ & & $\begin{array}{c}10 \\
0 \\
\end{array}$ & 58 & & 58 & 61 & & 59 & $\begin{array}{c}\text { Time to clinical } \\
\text { recovery }\end{array}$ \\
\hline $\begin{array}{c}\mathrm{Li} \mathrm{Y} \mathrm{et} \\
\mathrm{al}^{26}\end{array}$ & China & RCT & 3 & $\begin{array}{l}\text { L/R vs } \\
\text { Arbidol vs } \\
\text { Control }\end{array}$ & $\begin{array}{l}3 \\
4\end{array}$ & 35 & 17 & $\begin{array}{l}50 \\
.7\end{array}$ & $\begin{array}{l}50 \\
.5\end{array}$ & $\begin{array}{c}44 \\
.3\end{array}$ & 17 & 16 & 7 & Viral clearance \\
\hline $\begin{array}{l}\text { Lou et } \\
\mathrm{al}^{28}\end{array}$ & China & RCT & 3 & $\begin{array}{c}\text { B/M vs } \\
\text { Favipravir vs } \\
\text { Control }\end{array}$ & $\begin{array}{l}1 \\
0\end{array}$ & 9 & 10 & $\begin{array}{l}53 \\
.5\end{array}$ & 58 & $\begin{array}{c}46 \\
.6\end{array}$ & 7 & 7 & 7 & Viral clearance \\
\hline $\begin{array}{c}\text { Grein et } \\
\mathrm{al}^{22}\end{array}$ & USA & $\begin{array}{c}\text { Prospe } \\
\text { ctive }\end{array}$ & 1 & Remdesivir & $\begin{array}{l}5 \\
3\end{array}$ & & & 64 & & & 40 & & & Clinical course \\
\hline $\begin{array}{c}\text { Wang et } \\
\mathrm{al}^{21}\end{array}$ & China & RCT & 2 & $\begin{array}{l}\text { Remdesivir } \\
\text { vs Placebo }\end{array}$ & $\begin{array}{l}1 \\
5 \\
8\end{array}$ & & 78 & 66 & & 64 & 89 & & 51 & $\begin{array}{c}\text { Time to clinical } \\
\text { recovery }\end{array}$ \\
\hline $\begin{array}{c}\text { Luo et } \\
\mathrm{al}^{20}\end{array}$ & China & $\begin{array}{c}\text { Retrosp } \\
\text { ective }\end{array}$ & 1 & Tocilizumab & $\begin{array}{l}1 \\
5\end{array}$ & & & 73 & & & 12 & & & $\begin{array}{c}\text { Laboratory } \\
\text { improvement }\end{array}$ \\
\hline $\begin{array}{c}\text { Xu X et } \\
\mathrm{al}^{19}\end{array}$ & China & $\begin{array}{c}\text { Retrosp } \\
\text { ective }\end{array}$ & 1 & Tocilizumab & $\begin{array}{l}2 \\
1\end{array}$ & & & $\begin{array}{l}56 \\
.8\end{array}$ & & & 18 & & & Clinical course \\
\hline $\begin{array}{l}\text { Fang et } \\
\mathrm{al}^{29}\end{array}$ & China & $\begin{array}{l}\text { Retrosp } \\
\text { ective }\end{array}$ & 2 & $\begin{array}{c}\text { Oral Steroids } \\
\text { vs Control }\end{array}$ & 9 & & 46 & $\begin{array}{r}40 \\
.2\end{array}$ & & $\begin{array}{c}39 \\
.9\end{array}$ & 5 & & 22 & Viral clearance \\
\hline $\begin{array}{l}\text { Fang et } \\
\mathrm{al}^{29}\end{array}$ & China & $\begin{array}{l}\text { Retrosp } \\
\text { ective }\end{array}$ & 2 & $\begin{array}{l}\text { Intravenous } \\
\text { Steroids vs } \\
\text { Control }\end{array}$ & $\begin{array}{l}1 \\
6\end{array}$ & & 7 & $\begin{array}{l}60 \\
.6\end{array}$ & & $\begin{array}{c}54 \\
.3\end{array}$ & 12 & & 5 & Viral clearance \\
\hline $\begin{array}{c}\text { Guan et } \\
\mathrm{al}^{27}\end{array}$ & China & $\begin{array}{l}\text { Retrosp } \\
\text { ective }\end{array}$ & 1 & Steroids & $\begin{array}{l}2 \\
0 \\
4\end{array}$ & & & & & & & & & $\begin{array}{l}\text { ICU, Intubation, } \\
\text { Mortality }\end{array}$ \\
\hline $\begin{array}{l}\text { Lu et } \\
\mathrm{al}^{24}\end{array}$ & China & $\begin{array}{c}\text { Retrosp } \\
\text { ective }\end{array}$ & 2 & $\begin{array}{l}\text { Steroids vs } \\
\text { control }\end{array}$ & $\begin{array}{l}1 \\
5 \\
1\end{array}$ & & 93 & 64 & & 59 & 83 & & 45 & Mortality \\
\hline $\begin{array}{l}\text { Lu et } \\
\mathrm{al}^{24}\end{array}$ & China & $\begin{array}{c}\text { Retrosp } \\
\text { ective }\end{array}$ & 2 & $\begin{array}{c}\text { Steroid vs } \\
\text { control }\end{array}$ & $\begin{array}{l}3 \\
1 \\
\end{array}$ & & 31 & 57 & & 58 & 16 & & 16 & Mortality \\
\hline $\begin{array}{l}\text { Wu et } \\
\mathrm{al}^{17}\end{array}$ & China & $\begin{array}{c}\text { Retrosp } \\
\text { ective }\end{array}$ & 2 & $\begin{array}{l}\text { Steroids vs } \\
\text { Control }\end{array}$ & $\begin{array}{l}5 \\
0\end{array}$ & & 34 & & & & & & & Mortality \\
\hline $\begin{array}{c}\text { Wang Y } \\
\text { et al1 }{ }^{8}\end{array}$ & China & $\begin{array}{c}\text { Retrosp } \\
\text { ective }\end{array}$ & 2 & $\begin{array}{l}\text { Intravenous } \\
\text { Steroids vs }\end{array}$ & $\begin{array}{l}2 \\
6 \\
\end{array}$ & & 20 & 54 & & 53 & 16 & & 10 & Clinical course \\
\hline
\end{tabular}


medRxiv preprint doi: https://doi.org/10.1101/2020.05.20.20108365; this version posted May $23,2020$. The copyright holder for this preprint (which was not certified by peer review) is the author/funder, who has granted medRxiv a license to display the preprint in perpetuity. All rights reserved. No reuse allowed without permission.

\begin{tabular}{|c|c|c|c|c|c|c|c|c|c|c|c|c|c|c|}
\hline $\begin{array}{c}\text { Zhang } \\
\text { et al }^{16}\end{array}$ & China & $\begin{array}{c}\text { Case } \\
\text { Series }\end{array}$ & 1 & Plasma & 4 & & & & & & 2 & & & \\
\hline $\begin{array}{c}\text { Ahn et } \\
\mathrm{al}^{33}\end{array}$ & Korea & $\begin{array}{c}\text { Case } \\
\text { Series }\end{array}$ & 1 & Plasma & 2 & & & 69 & & & 1 & & & \\
\hline $\begin{array}{c}\text { Shen et } \\
\mathrm{al}^{31}\end{array}$ & China & $\begin{array}{c}\text { Case } \\
\text { Series }\end{array}$ & 1 & Plasma & 5 & & & & & & 3 & & & Clinical recovery \\
\hline $\begin{array}{c}\text { Duan et } \\
\mathrm{al}^{30}\end{array}$ & China & $\begin{array}{c}\text { Retrosp } \\
\text { ective }\end{array}$ & 1 & Plasma & 1 & & & 52 \\
\\
\hline $\begin{array}{c}\text { Ming et } \\
\mathrm{al}^{23}\end{array}$ & China & $\begin{array}{c}\text { Case } \\
\text { Series }\end{array}$ & 1 & Plasma & 6 & & & 64 & & & 3 & & & Adverse events \\
\hline
\end{tabular}

HCQ - Hydroxychloroquine; AZ - Azithromycin; L/R - Lopinavir/ Ritonavir; B/M - Baloxavir/ Marboxil; I1 - Intervention 1, I2 - Intervention 2; USA - United States of America; ECG Electrocardiogram

Table 2. Study outcomes in the intervention and control groups with odds ratios

\begin{tabular}{|c|c|c|c|c|}
\hline Outcome & Intervention group only & $\begin{array}{l}\text { Intervention group } \\
\text { studies common with } \\
\text { control group }\end{array}$ & $\begin{array}{l}\text { Control group } \\
\text { only }\end{array}$ & Odds ratio \\
\hline All-cause mortality & $\begin{array}{l}11.9 \%(95 \% \mathrm{Cl}: 7.7 \%-16.1 \%) \\
(\mathrm{n}=2071)\end{array}$ & $\begin{array}{l}16.2 \%(95 \% \mathrm{Cl}: 8.8 \%- \\
23.6 \%)(\mathrm{n}=1557)\end{array}$ & $\begin{array}{l}15.4 \%(95 \% \mathrm{Cl}: \\
9.1 \%-21.6 \%)(\mathrm{n}= \\
1110)\end{array}$ & $\begin{array}{l}1.22(95 \% \text { Cl: } 0.85-1.75, \\
\left.I^{2}=39 \%\right)(n=2667)\end{array}$ \\
\hline $\begin{array}{l}\text { Mechanical } \\
\text { ventilation rate }\end{array}$ & $\begin{array}{l}18.6 \%(95 \% \mathrm{Cl}: 10.9 \%- \\
26.3 \%)(n=1456)\end{array}$ & $\begin{array}{l}13.5 \%(95 \% \mathrm{Cl}: 7 \%- \\
19.9 \%)(n=1382)\end{array}$ & $\begin{array}{l}9.8 \%(95 \% \mathrm{Cl}: \\
4.5 \%-15.2 \%)(n= \\
935)\end{array}$ & $\begin{array}{l}1.58(95 \% \text { Cl: } 0.60-4.15, \\
\left.l^{2}=85 \%\right)(n=2317)\end{array}$ \\
\hline $\begin{array}{l}\text { Antiviral clearance } \\
\text { rate }\end{array}$ & $\begin{array}{l}80 \%(95 \% \mathrm{Cl}: 70.7 \%-89.4 \%) \\
(n=393)\end{array}$ & $\begin{array}{l}74.9 \%(95 \% \text { Cl: } 59.5 \% \\
-90.3 \%)(n=257)\end{array}$ & $\begin{array}{l}66.8 \%(95 \% \mathrm{Cl}: \\
42.6 \%-91.1 \%)(n= \\
204)\end{array}$ & $\begin{array}{l}1.86(95 \% \text { Cl: } 0.76-4.54, \\
l^{2}=58 \%(n=461)\end{array}$ \\
\hline $\begin{array}{l}\text { Clinical recovery } \\
\text { rate }\end{array}$ & $\begin{array}{l}79.7 \%(95 \% \mathrm{Cl}: 78.9 \%- \\
88.4 \%)(\mathrm{n}=558)\end{array}$ & $\begin{array}{l}64.1 \%(95 \% \text { Cl: } 51.5 \% \\
-76.8 \%)(n=340)\end{array}$ & $\begin{array}{l}56.9 \%(95 \% \mathrm{Cl}: \\
43.8 \%-69.9 \%)(\mathrm{n} \\
=243)\end{array}$ & $\begin{array}{l}1.41(95 \% \text { Cl: } 0.99-2.02, \\
\left.I^{2}=0 \%\right)(n=583)\end{array}$ \\
\hline $\begin{array}{l}\text { Progression to } \\
\text { severe disease }\end{array}$ & $\begin{array}{l}11.6 \%(95 \% \mathrm{Cl}: 5.4 \%- \\
17.8 \%)(n=387)\end{array}$ & $\begin{array}{l}13.4 \%(95 \% \mathrm{Cl}: 2.2 \%- \\
24.6 \%)(n=218)\end{array}$ & $\begin{array}{l}12.8(95 \% \mathrm{Cl}: 4.8 \% \\
-20.8 \%)(n=168)\end{array}$ & $\begin{array}{l}1.19(95 \% \mathrm{Cl}: 0.67-2.13, \\
\left.\left.\right|^{2}=0 \%\right)(n=386)\end{array}$ \\
\hline $\begin{array}{l}\text { Radiological } \\
\text { improvement rate }\end{array}$ & $\begin{array}{l}86.3 \%(95 \% \text { Cl: } 77.2 \%- \\
95.5 \%)(n=140)\end{array}$ & $\begin{array}{l}83.6 \%(95 \% \mathrm{Cl}: 67.6 \% \\
-99.7 \%)(n=107)\end{array}$ & $\begin{array}{l}82.6 \%(95 \% \mathrm{Cl}: \\
60.3 \%-100 \%)(\mathrm{n}= \\
60)\end{array}$ & $\begin{array}{l}1.02(95 \% \mathrm{Cl}: 0.13-8.07, \\
\left.\mathrm{I}^{2}=63 \%\right)(\mathrm{n}=167)\end{array}$ \\
\hline Discharge rate & $\begin{array}{l}69.8 \%(95 \% \text { Cl: } 60.3 \%- \\
79.3 \%)(n=1374)\end{array}$ & $\begin{array}{l}68.6 \%(95 \% \text { Cl: } 62.2 \% \\
-75 \%)(n=1171)\end{array}$ & $\begin{array}{l}78.6 \%(95 \% \mathrm{Cl}: \\
67.8 \%-89.4 \%)(\mathrm{n} \\
=800)\end{array}$ & $\begin{array}{l}0.55(95 \% \text { Cl: } 0.29-1.03, \\
\left.\mathrm{I}^{2}=81 \%\right)\end{array}$ \\
\hline $\begin{array}{l}\text { Adverse events } \\
\text { rate }\end{array}$ & $\begin{array}{l}23.3 \%(95 \% \mathrm{Cl}: 12.1 \%- \\
34.5 \%)(\mathrm{n}=791)\end{array}$ & $\begin{array}{l}34 \%(95 \% \mathrm{Cl}: 13.9 \%- \\
54.1 \%)(n=436)\end{array}$ & $\begin{array}{l}29.5 \%(95 \% \mathrm{Cl}: \\
9.4 \%-49.6 \%)(\mathrm{n}= \\
310)\end{array}$ & $\begin{array}{l}1.44(95 \% \text { Cl: } 0.70-2.94, \\
\left.I^{2}=62 \%\right)(n=754)\end{array}$ \\
\hline
\end{tabular}

\section{Figure legends:}


medRxiv preprint doi: https://doi.org/10.1101/2020.05.20.20108365; this version posted May 23, 2020. The copyright holder for this preprint

(which was not certified by peer review) is the author/funder, who has granted medRxiv a license to display the preprint in perpetuity.

All rights reserved. No reuse allowed without permission.

Figure 1 - PRISMA Flow diagram

Figure 2A - Odds ratio comparing all-cause in hospital mortality in intervention and control arms

Figure 2B - Odds ratio comparing all-cause in hospital mortality in intervention and control arms in hydroxychloroquine based studies

Figure 3A - Odds ratio comparing rates of mechanical ventilation in intervention and control arms

Figure 3B - Odds ratio comparing clinical recovery rates in intervention and control arms

Figure 4A - Odds ratio comparing adverse events rates in intervention and control arms

Figure 4B - Odds ratio comparing adverse events in intervention and control arms in HCQ based studies

\section{Appendix legends:}

Appendix 1 - PRISMA checklist

Appendix 2 - Medical Subject Entrée Terms used for search

Appendix 3 - Definition of outcomes

Appendix 4 - Risk of Bias summary for RCTs

Appendix table 1 - All cause mortality for various sub-groups

Appendix table 2 - Outcomes only for Randomized Controlled Trials 
medRxiv preprint doi: https://doi.org/10.1101/2020.05.20.20108365; this version posted May 23, 2020. The copyright holder for this preprint (which was not certified by peer review) is the author/funder, who has granted medRxiv a license to display the preprint in perpetuity. All rights reserved. No reuse allowed without permission.

Appendix figure 1 - Odds ratio comparing all-cause in hospital mortality in the interventions and control arms with severe disease

Appendix figure 2 - Odds ratio comparing all-cause in hospital mortality in the intervention and control arms for randomized controlled trials only

Appendix figure 3 - Odds ratio comparing viral clearance rates in intervention and control arms 


\section{PRISMA 2009 Flow Diagram}
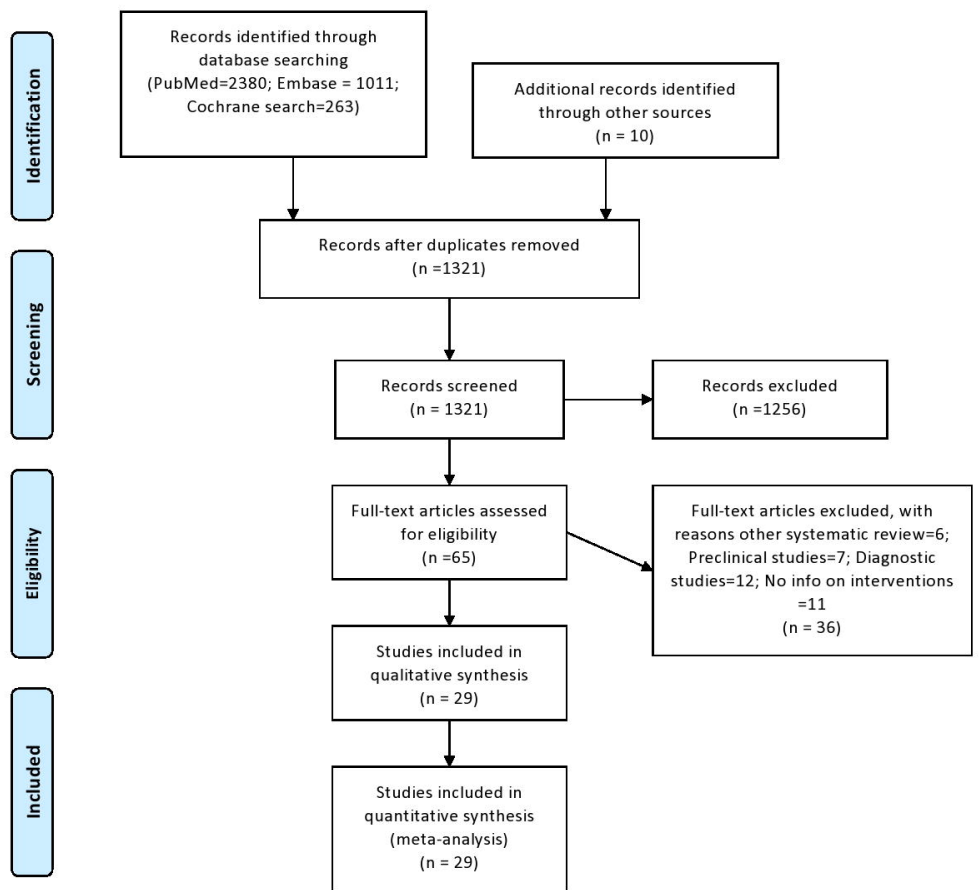
Studies

Nagacnoi 2020

Mahevas 2020

Geleris 2020

CaO 2020

L Y 2020

Lou 2020

Wang 2020

42020

Wu 2020

Wang Y 2020

Pcesnbeng 2020

Overal $\left\langle\left(\left.\right|^{n} 2=46.12 \%, P=0.045\right\rangle\right) 1.356(0.973,1.891\rangle \quad 534 / 2563 \quad 194 / 1331$

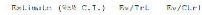

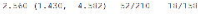

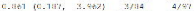

$1.531(1.135, \quad 2.007) \quad 151 / 811 \quad 73 / 365$

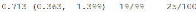

$0.202(0.005,13.190) \quad 0 / 08 \quad 0 \% 17$

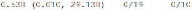

1.113: (11.4\%, 2.4\%3 $2 \% 1 \%$ 10\%

$1,589(0.5160 .9,622) \quad 10,21 \quad 12 / 31$

6. $227(1221 \%, 1.211\} \quad 23 /=00 \quad 21 \% 34$

$1.382(0.132,18,808) \quad 2 / 26 \quad 1 / 20$

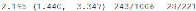

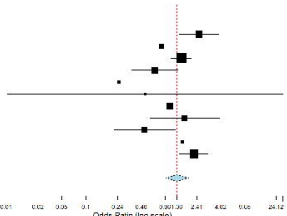




\section{Studies}

Magegnoli 2020

Naheves 2020

Golaris 2020

Roserberg 2020

Overall (l^ $2=29.71 \mathrm{X}, P=0.234) \quad 1.059 \quad(1.306,2.503) \quad 452 / 2111 \quad 125 / 1011$

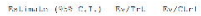

$2.560(1.130+1.082)=2 / 210 \quad 10 / 100$

C.

1.521 (1.128, 2.067: 154/811 78/558

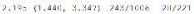

$$
\text { - }
$$

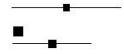

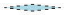

\begin{tabular}{|c|c|c|}
\hline 1 & 1 & 1 \\
\hline 31 & as & Odds zate \\
\hline
\end{tabular}

1

4 se 
Studies

Nagacnoi 2020

Geleris 2020

Cec 2020

$\sqcup \gamma 2020$

2020

Wang 2020

Fang 2020

Overal $\left(\mu^{\wedge} 2=85.21 \%, P<0.001\right)$

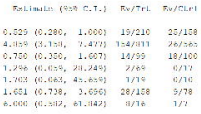

$79 / 935$

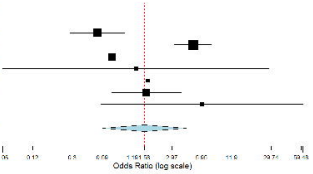


Studies

Teng 2020

$\mathrm{Can} 2020$

La 2020

Wiang 2020

Overal $\left(\left.\right|^{\wedge} z=0\right.$ \%, $P=0.977 \mid \quad 1.415 \quad(0.993,2.016) \quad 224 / 340 \quad 141 / 243$

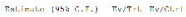

1.292 (0.626, 2.661) 32,6!

$1.54 \%$ (1.5.50, 5.13\%) (!., 44

1.375 (0.295, 5.402) -1.19

$1.565(13.344,2.344)$ 105, $5 !$

21,55

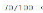

$5 / 10$

$4.5,81)$
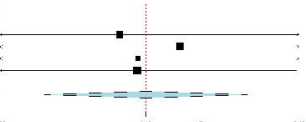

octs Feto (boj scsie) 
studies

Chen Z 2020

Tang 2020

$\mathrm{CoO} 2020$

iY 2020

Los 2020

Wang 2020

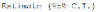

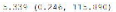

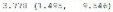

1.082 6.610, 1.901)

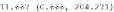

$0.22860 .047,1.218$ ?

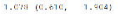

Tie, TrL Tivitar.

\begin{tabular}{|c|c|}
\hline $2,2: 7$ & $6 / 2: 57$ \\
\hline $2721=$ & 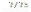 \\
\hline $46 / 95$ & $16 \gamma 99$ \\
\hline $71,80=$ & $6 / 17$ \\
\hline 819 & 610 \\
\hline $167,7=2$ & $z x / \gamma 1$ \\
\hline
\end{tabular}

Overall (la $2=62 \%, P=0.022) \quad 1.436(0.701, \quad 2.941) \quad 153 / 441 \quad 109 / 310$

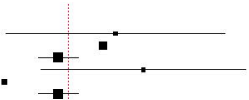

$1 \quad 1$

12

1
$3 \pm 3$

1

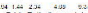
odds fario (b) scale)

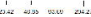


Studies

Chen 22020

Tang 2020

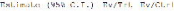

$5.33919 .210,425.3901 \quad 2 / 31$

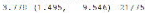

9. 115) 23/106

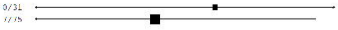

Has $=\square=$ 


\section{Studies}

Can 2020

Wang 2020

2020

Viv 2000

Wang $Y 2020$

Overall $\left(l^{\wedge} z=0 \%, P=0.438 \mid \quad 0.876 \quad(0.585,1.310) \quad 82 / 364 \quad 69 / 263\right.$
Loimate loos C.L.) britzt bvicter

\begin{tabular}{|c|c|c|c|c|}
\hline 1.713 & 4. 363. & $(1.344)$ & $3 4 \longdiv { 4 4 }$ & $5 / 9$ \\
\hline 1.100 & 10.493 & $2.453 j$ & $22 ; 158$ & $10 / 78$ \\
\hline 1.000 & $10.01 \theta^{\circ}$ & 4.0.3:3) & 2,87 & $1 \% / 31$ \\
\hline 0,52 & $13.21 \%$ & 1.2813 & 23853 & $21 / 31$ \\
\hline . & $\{0.13$ & 78.18013 & $2 \sqrt{26}$ & 17 \\
\hline
\end{tabular}

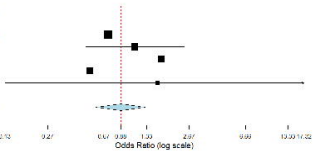




\begin{tabular}{|c|c|c|c|c|c|c|c|c|c|c|c|c|c|c|}
\hline studies & T.stimsta: iy & Sii $(. . T-1$ & $T V / T$ I. & Tig/ct.ri & & & & & & & & & & \\
\hline $\operatorname{Coo} 2020$ & $0.713 \quad 10.363$ & $1.300 j$ & $-9 / 90$ & 20,100 & & & & & & & & & & \\
\hline LY 2020 & $3.75 \%$; 30135, & 13.1439 & $3 / 04$ & $a / 18$ & $\therefore$ & & & & - & & & & & \\
\hline 2020 & $0.538 \quad 10.010$ & $29.138 j$ & $0 ; 19$ & $0 / 10$ & . & & & & & - & & & & $\therefore$ \\
\hline Wang 2020 & $1.100 ; 0.445$ & $\% .45 .3)$ & $22 />3 !$ & $10 / 48$ & & & & & & & & & & \\
\hline \multirow[t]{3}{*}{ Overall $\left(\left.\right|^{\wedge} 2=0 \%, P=0.786 \mid\right.$} & $0.930(0.199$, & $1.379)$ & $\pm 1 / 345$ & $35 / 205$ & & & & & & & & & & \\
\hline & & & & & ond & ons & $\log _{2}$ & $\begin{array}{c}1 \\
013\end{array}$ & 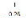 & $n \in=$ & 485 & 3. 2.1 & $=1$ & $\frac{1}{1313 \times c o}$ \\
\hline & & & & & & & & & octss & tio & celes & & & \\
\hline
\end{tabular}


Studies

Chen $\sqrt{2020}$

Gautrot 2020

Teng 2020

$\operatorname{Can} 2020$

Li $Y 2020$

Lo. 2020

Overall $\left(\left.\right|^{\wedge} 2=58.08 \mathrm{X}, \mathrm{P}=0.036\right)$

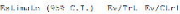

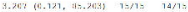

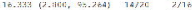

$1.192(0.617,2.605)$ 6.75 617\%

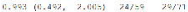

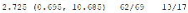

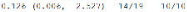

$1.062(0.764,4.541) \quad 194 / 257 \quad 129 / 201$
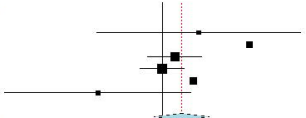

${ }_{301}^{1}$

1

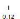

1

$\begin{array}{lllll}1 & 1 & 1 & 1 \\ 1 & 1 & 1 & 1\end{array}$ onds failo flog srale 